\title{
Early Childhood Pre-Service Teachers' Perspectives on Play and Teachers' Role
}

\author{
Zubeyde Dogan Altun ${ }^{1}$ \\ ${ }^{1}$ College of Education, Dokuz Eylul University, Izmir, Turkey \\ Correspondence: Zubeyde Dogan Altun, College of Education, Dokuz Eylul University, Izmir, Turkey. Tel: \\ 90-50-7740-9368. E-mail: zubeyded@yahoo.com
}

Received: April 12, 2018

Accepted: May 25, $2018 \quad$ Online Published: July 28, 2018

doi:10.5539/ies.v11n8p91

URL: https://doi.org/10.5539/ies.v11n8p91

\begin{abstract}
The purpose of the study is to understand the early childhood teacher candidates' perception of play and their understanding of teachers' role in play. Another aim of the study is to disclose pre-service teachers' thoughts on their college training adequacy regarding the play. In this qualitative research, the data came from written responses of the fifty five participants who are in their $4^{\text {th }}$ year studying early childhood education at the public teaching college located in the west part of Turkey. The findings of the research suggest that fun is the most distinguished feature of play. The other attributes of play mentioned by participants were relaxation/energy release, freedom, cooperation and rules. Pre-service teachers have different perspectives on teachers' verbal and physical participation in ongoing play activity. Their thoughts led three different subcategories of teachers' participation in play which are partial-participation, non-participation, and full-participation. And finally, the findings revealed four different teachers' roles as Planner/Organizer, Observer/Guider, Play Partner, and Non-involver according to participants' responds.
\end{abstract}

Keywords: children's play, teachers' role, teacher education, pre-service teachers

\section{Introduction}

The significant role of play in child development and learning has been well established in the field of early childhood (Enz \& Christie, 1993; Wood \& Bennett, 1998). Many leading organizations' position statements emphasize on the value of play in children learning and development. For instance, Association for Childhood Education International states that play “ $\ldots$ is an essential and integral part of all children's healthy growth, development, and learning across all ages domains, and cultures" (Isenberg \& Quisenberry, 2002, p. 33). Even though the value of play in learning and development is accepted and the play based curriculum is favored in the field, how play is placed in the classrooms by teachers is still uncertain (Rengel, 2014; Wood \& Bennett, 1998). In early childhood settings, children's learning experience depends on teachers' pedagogical view, knowledge and willingness to put the theory into the practice. Therefore, teachers, who understand the value of play and know how they can contribute children's learning and development, can create a classroom environment in which children acquire all benefits that play can offer (Van der Aalsvoort, Prakke, Howard, König, \& Parkkinen, 2015).

Teachers develop the theories or ideologies of play mostly during their training in universities and when they become teachers, they most likely use those ideas in their classrooms. Nonetheless, there is no enough research on teacher candidates' view on play in children's education (Sherwood \& Reifel, 2010; Van der Aulsvood et al., 2015). This study aims to understand the teacher candidates' perception of play and their understanding of teachers' role in children's play. It also intends to find out whether prospective teachers think their training is adequate enough to make them feel comfortable to use play as a learning context in their future classroom practices.

\subsection{Significance of the Study}

Although there are a significant amount of researches on children's play in early childhood, pre-service teachers' perspective on play and teachers' role in it are less addressed in the research literature (Fleer, 2015; Sherwood \& Reifel, 2010). Studying pre-service teachers' perspectives on play may give us some understandings about their later classroom practices since they will develop their perspectives about play and its role in child education based on what they are taught during their training (Sherwood \& Reifel, 2010; Van der Aulsvood et al., 2015). Given the 
foregoing, this study aims to give insights about Turkish preschool teacher candidates' perspectives on and teachers' roles in play in early childhood settings.

\subsection{Review of the Literature}

\subsubsection{Play and Development}

Play is considered as to be fun and enjoyable, voluntary, and process oriented and generally it does not have any external goal for the player (Ashiabi, 2007). Play is essential in children's development and learning since it has a significant role on children's cognitive, physical, social, and emotional well-being (Bergen, 2002). Literature suggests that play supports children's cognitive development in different aspects such as perspective-taking, memory, language skills, and creativity (Isenberg \&Quisenberry, 2002; Stegelin, Fite, \& Wisneski, 2015).

Play contributes many aspects of child development (Lillard, Lerner, Hopkins, Dore, Smith, \& Palmquist, 2013). For instance, Ashiabi (2007) argues that participation of play enhance children's socioemotional development because in play, children obtain ability to negotiate with their peers, learn how to be cooperative, and improve sensitivity to others' needs and feelings. Play creates a social context where children learn to use language as a tool to communicate with others in a meaningful way (Weisberg, Zosh, Hirsh-Pasek, \& Golinkoff, 2013). Isenberg and Jalango (2002) points out the supportive role of play in stimulating children's creative thinking and imagination because children feel free to try new and alternative ways while they are playing.

Nowadays in Turkey, like many other countries, play is placed in the center of early childhood curriculum. In 2013, the National Early Childhood Education Program assembled by Ministry of National Education (MoNE) updated early childhood education program and suggested a play based learning. Play is pointed out as a tool that children learn and understand the world around them and they should be taught using playful activities (MoNE, 2013). The guidelines of curriculum give teachers some suggestions about involvement in play but still there are some researches on teachers' classroom practices showing that teachers hardly provide play opportunities to their students (Ivrendi \& Işııkoğlu-Erdoğan, 2015). Moreover, to researcher's knowledge, there is not any research on teacher candidates' perspective on play after the updated national early childhood education program.

\subsubsection{Teachers' Role in Children's Play}

While the importance of play in children's development is generally agreed on, there is an ongoing controversy about the degree on teachers' involvement in children's play (Tsai, 2015). These different ideas come from variety of pedagogical understanding of children's learning, education and play's role (Fleer, 2015; Wood \& Bennett, 1998). Traditionally, children's play conceptualized as child guided activity that children do themselves without any adult involvement (Trawich-Smith \& Dziurgot, 2011). From this perspective, child guided play viewed as the most beneficial for children and teacher should not interfere in it. The theorists argued that teacher involvement can interfere children's play which may limit to the highest developmental and learning benefits of play. Also, teachers may have different agendas such as teaching academics that their involvement may faint the natural flow of play (Enz \& Christie, 1997). On the other hand, some researches show that there is no guarantee that quality of learning outcomes are reached through child guided play (Wood, 2008). Studies from socio-cultural perspective indicate that teacher or adult involvement can have positive impact in children's play and learning. They conclude that teacher involvement can enhance children's play abilities and facilitate their social, cognitive and language development (Enz \& Christie, 1997; Smilansky \& Shefatya, 2010).

Research literature on teacher's perspective on play showed that even though teachers value play in the classroom settings, they have different views on involving children's play in their classrooms. Some of them believe that their role is only organizing environment and the others believe the value of direct involvement in play. Enz and Christie (1993) studied teachers' play interaction styles and concluded that teachers use four different styles which are stage manager, co-player, play leader and director roles. The stage manager style includes making props and materials accessible, responding children's needs, and organizing the play environment. In co-player style, teachers take an active but a minor role in children's play. In play-leader role, as similar to the co-player style, teachers are active in play episodes and have extended role such as being a leader introducing new elements in ongoing play episodes. Finally, in director role, teachers decide the play theme and the children who are going to be actors in the play. In this style, teachers stay out of the play and give some directions or ask direct questions to the children during the play. In her study, Kontos (1999) observed 40 teachers and found that most of the teacher's role in children play were either helping children to involve in the play (stage manager) or facilitate children's ongoing play activity (play enhancer).

\subsubsection{Teacher Training in Turkey}

In Turkey, department of early childhood education offers four year training program to the candidates who want 
to be a teacher in public or private preschools. During this four year training program, students take theoretical classes about child development and specific learning subjects such as language and numeracy. One semester in the third year, and two semesters in the fourth year, students are planned to go to public schools for practical training. During the whole four year program, there is only one class offered about the play.

\section{Method}

This study was a basic qualitative study (Merriam, 1998). A basic qualitative research commonly used in education was described by Merriam (1998) as "Here the researcher is interested in understanding the meaning of a phenomenon has for those involved" (p. 22). Since, the aim was to understand the meaning of play for the pre-service teachers, the basic qualitative research design seemed to suit to this study. In this study, open-ended questions were used to obtain written responses from the participants.

\subsection{Participants}

Fifty five students in their $4^{\text {th }}$ year from the public teaching college located in the west part of Turkey participated in this study. All participants were from Faculty of Education studying the early childhood education. Fifty of them were female and five of them were male and their participation was on a voluntary basis.

\subsection{Data Collections}

The data came from written responses of the participants, and collected in June 2017, which was the last semester of their fourth year. Onset of the data collection, the purpose of the research was explained to the participants. They were asked not to mention their names on the paper. Additionally, it was explained that the research findings would not give any information that may disclose their identity. The researcher has not been their lecturer in any classes during their four year training and did not share the findings with any participants' lecturers.

The research questions guided the study were: (1) Can you explain what play means for you? (2) What do you think about the teacher's role in children's play? (3)What do you think about your training on play during your study?

\subsection{Analyzing of Data}

After gathering answers from the participants, the data were read and re-read by the researcher to become familiar with the data. Participants' responses were coded and categorized by the guidance of the research questions. Finally, the findings conceptualized and conclusions were drawn connected with relative literature. One of the colleagues of the researcher coded the responses independently as well. To assess interrater reliability, Miles and Huberman (1994) formula (number of agreement/number of agreement + number of disagreement) was used. Initially, 5 of the participants' responses randomly chosen and coded by two independent coders and agreement were $60 \%$. Then, the coders went back to the data and according to agreement and disagreement, some codes added and some revisions of the codes were made. Later, 5 other participants' responses were coded independently and the agreement was calculated as $80 \%$.

\section{Results}

\subsection{The Meaning of Play}

Table 1. Responses to the question of what is play?

\begin{tabular}{lcc}
\hline Responses & Pre-service Teachers (N=55) & Percentage (\%) \\
\hline Self-Expression & 17 & 15 \\
Imagination & 5 & 4 \\
Fun & 35 & 31 \\
Relaxation/Energy Release & 9 & 8 \\
Freedom & 4 & 4 \\
Cooperation & 3 & 3 \\
Rules & 2 & 2 \\
Development & 15 & 13 \\
Learning & 23 & 20 \\
\hline
\end{tabular}

As displayed on Table 1 above, the data revealed nine attributes in regard to the meaning/definition of play. Most of the participants consider the play as a fun activity. Their comments showed that fun is the most distinguished feature of play. Self-expression was another attribute that data revealed. The other attributes mentioned by 
participants were relaxation/energy release, freedom, cooperation and rules. Followings are some example statements demonstrating of participants thoughts;

Play is the way for the children to express themselves freely (Participant 25).

Play is an activity through which children enjoy, move freely and follow the rules (Participant 3).

Play is a self-expression with fun and relaxation (Participant 13).

Play is an activity that children use their imagination, take different roles and having competition with their friends (Participant 41).

Pre-service teachers' definition of play entailed the relationship between play and children's learning and development. "Play is the most effective way of children's learning" or "Play is an activity through which children learn and have fun". Aforementioned two examples displayed interaction between play and learning. The role of play in children's development was also commonly mentioned by the participants. Some example statements are; "Play contributes children's physical, emotional and cognitive developments", "Play is the activity by which children's development reaches the highest level".

\subsection{Teachers' Role in Children's Play}

In order to understand teacher candidates' perspective on the role of teachers in children's play, 55 participants were asked their opinion on this subject. The findings of the study revealed that the prevailing idea among participants is that play themes are to be decided and rules are defined in advance by the teachers. Teacher candidates in this study commonly recognized play as a tool to teach pre-defined learning objectives, skills and/or target behaviors, and they reflect the idea that teachers should decide play themes based on these objectives. Followings are some examples of their thoughts;

Teachers should find different play themes by which children can learn and have fun at the same time (Participant 41)

Teachers should use play as a tool to teach the learning objectives and know more about the children (Participant45)

As a teacher, I will select plays that may help to develop children's creativity and improve the children's social interaction (Participant55)

Having examined the data, it demonstrated that the participants have different perspectives on teachers' participation namely verbal and physical involvement in play activity. Their thoughts led three different subcategories of teachers' participation (active involvement) in ongoing play which are partial- participation, non-participation, and full-participation as described in detail below.

\section{Partial-participation}

40 out of 55 participants think that teacher's role is to stay out of the play flow and only involve if there is any problem occurs, or if any children needs encouragement to play or the activity does not go the way as planned. This group of participants regards the teachers' involvement as intervention of the ongoing play. The following quotes are some examples of the participants' answers.

I think the teacher should stay out of the play, observe and interfere in when necessary (Participant 16).

Teacher should give directions to start the play then stay on side and make sure the participation of all the students (Participant 2)

\section{Non-participation}

8 of the participants comment that teachers should be out of the play after it starts and not involve in it under any circumstances. Teacher should organize the appropriate environment and make sure that safety precautions are in place. Here is the one quote from the participant.

Teacher role is to allow children to discover their own world by staying away and prepare environment and take all the precautions in advance (Participant 34)

\section{Full-participation}

Only 7 of the participants indicated that teachers should join in children's play and become the part of the ongoing activity. Following quotes are some examples of the participants' answers.

... I strongly believe that teacher should be actively participate in the play (Participant50)

Teacher joins play as an active play partner (Participant 40) 
Overall, based on the results, common thoughts of participants on teachers' roles in children's play are categorized as follows;

Planner/Organizer; In this category, teachers take some roles such as selecting the play themes, organizing the appropriate environment, supplying the play materials needed, describing the rules to children and giving start to the play activity.

Observer/Guider; during the play, teachers' main role is to observe the children. They only interfere in if there is any conflict among children or if the play does not go the way as it's planned. They step in the play shortly to correct the situation and step out as soon as possible. Participants draw attention to the importance of the teachers' role to encourage all the children to involve in the play.

Play Partner: this role refers to the teachers' involvement in play as a play partner of the ongoing play activity. Teacher can join the activity by his/her free will. According to some participants Co-playing with children is a good strategy because it facilitates the play, enable teacher to learn more about the students and improve the relationship between the teacher and the children.

Non-involver; after the play starts, the teachers stay out of the activity and do not involve any part of the play. By doing this, children learn to solve their problems by themselves and improve their social skills based on the answers.

\subsection{Ideas of Teacher Candidates on Adequacy of University Training on Play for Their Future Teaching Practices}

The data yielded 3 different common thoughts from the question above. According to the results, 25 participants think that the university training was not enough or did not contribute their knowledge of play. This group explained that the classes they took about the play were either very limited or did not help them to understand the play comprehensively. Following quotes are some examples of the participants' answers.

No, I do not think so because the class was more theoretical than practical and the instructors did not pay enough attention (Participant 37).

No, I do not agree! I try to get some training from the private courses and seminars to improve my knowledge (Participant43).

10 participants think that the training was partially enough. The participants find the classes more theoretical than practical. Due to the lack of practical training, pre-service teachers do not feel comfortable and qualified to apply play in their teaching practices. Here are some examples from the participants' answers.

Yes, it was partially enough! I consolidate my knowledge from the class during my internship with the classroom teachers (Participant42).

Theoretically yes but practically need to be improved (Participant 45).

At last, 20 participants mention that they had adequate training and they can use the play on their classroom practices. Below are some examples of the participants' thoughts.

Yes! We had adequate play class and that's why I feel qualified (Participant 26).

Yes! We have immense play repertoire due to the play class with the modern educational methods (Participant48).

\section{Discussion}

The findings of the study suggested that pre-service teachers used a combination of characteristics to explain the meaning of play that are parallel to the universal norms. The common terms used to define play were self-expression, imagination, fun, relaxation/energy release, freedom, cooperation and rules. The pre-service teachers also pointed out the close connection between play and children's learning and development. They recognized play as an important context in which learning and development occurs. This finding has an important meaning because it revealed that the participants value the play in children's learning and development. This also gives a hint that they have positive attitude towards employing play in their future classroom practices. Nowadays, in many countries such as USA, there is a pressure for teaching young children academics and skills instead of play and this pressure may lead diminishing of play in early childhood classrooms (Pistorova \& Slutsky, 2017). Therefore, future teachers' positive attitude towards play is very important in ensuring play to find its valuable place in the classrooms.

The current study reveals that teachers have multiple roles in children's play based on participants' opinions. According to them, teachers plan and organize the play by providing the materials and safe environment, selecting 
appropriate play theme and setting the rules. During the play, teachers observe the ongoing play activity, guide the children to follow the rules and step in to solve any conflicts. Though, it was a rare idea, the other role of teachers was being a play partner. Many researches from different countries find similar ideas on teacher's role in children's play (Yang, 2013).

Majority of the participants of this study prefer teachers to stay outside of the play. Pre-service teachers perceive teacher participation in children play as an interruption of the ongoing play activity. They think that teacher should stay out of the play to observe, guide and solve any problem when/if needed. From their point of view, after the play starts, children should play by themselves as long as they follow the rules and the flow of the structured play. It is obvious that there is a conflict in their ideas of teacher involvement in children play. On the one hand, they think that teacher should let children play on their own without an interruption, on the other hand, they stress on teachers' various involvement such as picking the play theme, distributing the roles and making sure that rules of the play are followed (McClintic \& Petty, 2015). Thus, it seems that there are two ideas conflicting with each other. Their idealization of play is still child centered in which children play themselves without adult participation. Contrarily, their models of teacher role in educating children are teacher centered through which teacher initiates and somehow control the activity in the classroom settings.

The findings of the study points out the necessity of better understanding of play and play pedagogy by teacher candidates. First of all, it is obvious that the future teachers and the academicians will benefit from some clarifications and agreements on definitions of play and play pedagogy and teacher role in it (Van Oers, 2013). Even though, prospective teachers perceive play and learning as inseparable, they did not seem to comprehend thoroughly how to do that properly. Their theories about play are from cognitive perspective (Wood \& Benett, 1998) and their perception of teachers' role in children's learning is a teacher centered. Therefore, some agreement about how to apply play in the classrooms and give some guidance accordingly may help to develop play classes in the teacher education programs. This is very important to make sure that play keeps its deserved place in early childhood classrooms in the future. Finally, it is suggested that further researches from different countries are required in order to improve our understanding of play from different cultural point of view.

As a researcher, I suggest to teach all play forms that can be seen in the classrooms and teachers' role correspondingly at colleges. Participants interpret that the adult involvement may interrupt children's ongoing play. This is a learned assumption that they are going to apply in their classrooms and most likely hesitate to involve any child initiative play. Then the question is whether this hesitation of involvement may reduce the benefits of adult participation in children's play. Because some of the research demonstrated that not all children play levels are the same and some may need adult scaffolding. On the other hand, the participants favor of guided play with the purpose of teaching some learning subjects in their mind. In that case, the question is if teacher candidates be able to teach something within play without it becoming teacher guided activity. Another important point is the needs of the prospective teachers on practical implication. There seems to be a gap between what they learn in colleges and the real classroom practices. Therefore, it can be beneficial to have more collaborative works between colleges and preschools in order to help prospective teachers to put their knowledge into the practice.

\section{References}

Ashiabi, G. (2007). Play in the preschool classroom: Its socioemotional significance and the teacher's role in play. Early Childhood Education Journal, 35(2), 199-207. https://doi.org/10.1007/s10643-007-0165-8

Bergen, D. (2002). The role of pretend play in children's cognitive development. Early Childhood Research and Practice, 4(1), 1-8.

Enz, B., \& Christie, J. F. (1993). Teacher play interaction styles and their impact on children's oral language and literacy play. Paper presented at the Annual Meeting of the National Reading Conference, Charleston, USA.

Fleer, M. (2015). Pedagogical positioning in play: Teachers being inside and outside of children's imaginary play. Early Child Development and Care, 185, 1801-1814. https://doi.org/10.1080/03004430.2015.1028393

Isenberg, J. P., \& Quisenberry, N. (2002). A position paper of the association for childhood education international play: Essential for all children. Childhood Education, 79(1), 33-39. https://doi.org/10.1080/00094056.2002.10522763

Ivrendi, A., \& Isikoglu-Erdoğan, N. (2015). Play in Turkey. In J. L. Roopnarine., M., Patte, J. E. Johnson, \& D. Kuschner (Eds.), International Perspectives on Children's Play. Open University Press/McGraw Hill Education ISBN: 978-0335262885.

Kontos, S. (1999). Preschool teachers' talk, roles, and activity setting during free play. Early Childhood Research Quarterly, 14(3), 363-382. https://doi.org/10.1016/S0885-2006(99)00016-2 
Lillard, A. S., Lerner, M. D., Hopkins, E. J., Dore, R. A., Smith, E. D., \& Palmquist, C. M. (2013). The impact of pretend play on children's development: A review of the evidence. Psychological Bulletin, 139(1), 1-34. https://doi.org/10.1037/a0029321

McClintic, S., \& Petty, K. (2015) Exploring early childhood teachers' beliefs and practices about preschool outdoor play: A qualitative study. Journal of early childhood teacher education, 36(1), 24-43. https://doi.org/10.1080/10901027.2014.997844

Merram, S. (1998). Qualitative research and case study applications in education. San Francisco.

Miles, M. B., \& Huberman, A. M. (1994). Qualitative data analysis: An expended Source book. Sage Publication.

Ministry of National Education (MoNE). (2018). National Early Childhood Education Program. Retrieved from https://tegm.meb.gov.tr/dosya/okuloncesi/ooproram.pdf

Pistorova, S., \& Ruslan, S. (2017). There is still nothing better than quality play experiences for young children's learning and development: Building the foundation for inquiry in our educational practices. Early Child Development and Care, 188(5), 495-507. https://doi.org/10.1080/03004430.2017.1403432

Rengel, K. (2014). Preschool Teachers' Attitudes towards Play. Croatian Journal of Education, 16, 113-125.

Sandberg, A., \& Pramling-Samuelsson, I. (2005). An interview study of gender differences in preschool teachers' attitudes toward children's' play. Early Childhood Education Journal, 32(5), 297-305. https://doi.org/10.1007/s10643-005-4400-x

Sherwood. S. A. S., \& Reifel, S. (2010). The multiple meanings of play: Exploring preservice teachers' beliefs about a central element of early childhood education. Journal of Early Childhood Teacher Education, 31(4), 322-343. https://doi.org/10.1080/10901027.2010.524065

Smilansky, S., \& Shefatya, L. (1990). Facilitating play: A medium for promoting cognitive, socio-emotional and academic development in young children. Gaithersburg, MD: Psychosocial and Educational Publications.

Stegelin, D., Fite, K., \& Wisneski, D. (2015). The critical place of play in education. US Play Coalition. South Carolina: Clemson University. Retrieved from https:/usplaycoalition.org/wp-content/uploads/2015/08/ PRTM-Play-Coalition-White-Paper.pdf

Trawick-Smith, J., \& Dziurgot, T. (2011). 'Good-fit' teacher-child play interactions and the subsequent autonomous play of preschool children. Early Childhood Research Quarterly, 26, 110-123. https://doi.org/10.1016/j.ecresq.2010.04.005

Tsai, C. Y. (2015). Am I interfering? Preschool teacher participation in play. Universal Journal of Educational Research, 3(12), 1028-1033. https://doi.org/10.13189/ujer.2015.031212

Van der Aulsvood, G., Prakke, B., Howard, J., König, A., \& Parkkinen, T. (2015). Trainee teachers' perspectives on play characteristics and their role in children's play: an international comparative study amongst trainees in the Netherlands, Wales, Germany and Finland. European Early Childhood Education Research Journal, 23(2), 277-292.https://doi.org/10.1080/1350293X.2015.1016807

Van Oers, B. (2013). Is it play? Towards a reconceptualization of role play from an activity theory perspective. European Early Childhood Education Research Journal, 21(2), 185-198. https://doi.org/10.1080/1350293X.2013.789199

Weisberg, D. S., Zosh, J. M., Hirsh-Pasek, K., \& Golinkoff, R. M. (2013). Talking it up: Play, language, and the role of adult support. American Journal of Play, 6(1), 39-54.

Wood, E. (2008). Contestation, transformation and re-conceptualisation in early childhood education. The Routledge Reader in Early Childhood Education (pp. 1-18). London: Routledge.

Wood, E., \& Bennett, N. (1998). Teachers' theories of play: Constructivist or social constructivist? Early Child Development and Care, 140(1), 17-30. https://doi.org/10.1080/0300443981400103

\section{Copyrights}

Copyright for this article is retained by the author(s), with first publication rights granted to the journal.

This is an open-access article distributed under the terms and conditions of the Creative Commons Attribution license (http://creativecommons.org/licenses/by/4.0/). 